STUDIA PRAWNO-EKONOMICZNE, t. CIV, 2017

PL ISSN 0081-6841; e-ISSN 2450-8179 $\quad$ s. 287-301

DOI: 10.26485/SPE/2017/104/16

Paweł MIKOŁAJCZAK*

\title{
SUSTAINABLE BANKING. IMPLICATIONS FOR AN ETHICAL DIMENSION OF FINANCE OF SOCIAL ENTERPRISE PERFORMANCE
}

\begin{abstract}
(Summary)
The article evaluates potential of sustainable banking as an important element of ethical finance system, supporting social enterprises financially. The article describes an alternative character of ethical banking against the risks resulting from the involvement of social external investors into investment ventures realized by social enterprises. Thus, it analyzes selected financial indexes of ethical banks against commercial banking institutions and it also assesses principles and criteria of finance by sustainable banking. Conclusions refer to non-credit forms of social enterprise finance.
\end{abstract}

Keywords: sustainable banking; social entrepreneurship; credit; ethical finance

JEL Classification: G01, G22, G23, L31

\section{Introduction}

Modern commercial banks are strongly oriented to using a financial leverage to maximize profits, contributing to excessive financialization of economy and creating conditions for crisis ${ }^{1}$. Increase in importance and value of financial assets in comparison to tangible assets occurs. Also, importance of financial motives increases, most of all, of those referring to the profit and risk in a process of making economic decisions, and their influence on an effective performance of economic entities and social behaviors ${ }^{2}$. Financialization may contribute to conflicts between

* Ph.D., The Department of Money and Banking at Poznań University of Economics; e-mail: pawel.mikolajczak@ue.poznan.pl

1 M. Ratajczak, Ekonomia i edukacja ekonomiczna w dobie finansyzacji gospodarki, Ekonomista 2012/2, pp. 207-220.

2 K. Jajuga, W poszukiwaniu miar ryzyka finansowego, in: J. Czekaj, S. Owsiak (eds.), Finanse w rozwoju gospodarczym i spolecznym, PWE, Warszawa 2014, pp. 147-157. 
an industrial sector, financial sector and labor market. It influences negatively an employment sphere and consequently, social unity of economies.

Since the $60 \mathrm{~s}$ and $70 \mathrm{~s}$, along with the development of social movement, the birth of sustainable banking can be observed, also referred to as ethical or social ${ }^{3}$. Sustainable banks more intensively than traditional banks react to the needs of both entities which are excluded from a common banking system and people saving and investors, shaping a social direction of their savings placement. They aim at a positive social or ecological impact in a process of collecting and using capital by investing in ecological agriculture, renewable green energy, social economy entities, including social enterprises. The latter are private entities which usually realize goals different from profits. Their priority is not to generate financial benefits for their owners and parties involved, but provide products and services, both to the needs of their members and community. However, because of a specific character of their performance, they are deprived of a possibility to collect funds from traditional banking. Thus, they are strongly dependent on public aid and capital coming from outer investors. Investment motives of the latter are determined on one hand by economic factors and social on the other. Expectations of investors towards a particular return of investment may endanger essential functions of social enterprises.

In light of such a background, the aim of this paper is on one hand to evaluate potential of sustainable banking as an important element of ethical finance system, supporting social enterprises financially, and on the other hand show ethical banking as an alternative to risks resulting from involvement of social external investors into investment ventures realized by social enterprises. The thesis reads as follows: sustainable banking may be an alternative to a limited access to financing entities of social economy without putting them at risk of them moving away from their social role.

\section{Dilemmas of social enterprise performance finance}

Performance of social enterprises, just like other economic entities, is greatly dependent on a possibility of raising various financial funds ${ }^{4}$. Holders of the latter, on the other hand, except for realizing a social mission, depending on a financial

3 O. Weber, Sustainable Banking-History and Current Developments, Social Science Research Network 2016/1, pp. 2-18.

4 A. Brown, W. Norman, Lighting the Touch-Paper: Growing the Social Investment Market in England, Boston Consulting Group \& the Young Foundation, Report commissioned by Big Society Capital November, England 2011. 
vehicle of support, expect specific profitability, or at least return of investment ${ }^{5}$. Consequences of social entrepreneurship finance from strange sources, mainly from outer investors may have a dichotomic character towards its social role, being in opinion of some authors kind of confrontation between two contrary values $^{6}$. What is more, realization of some of the social ventures often requires strong entrepreneurial orientation and using complicated business patterns by the discussed units 7 . It poses a risk of bigger concentration of social enterprises on selected-more profitable projects accompanied by limitation of ventures in different areas, e.g. for needs of particularly poor people, who cannot afford to pay for services provided, even in a situation of an absolutely preferable price. There is also a risk of rejection of providing cheap or free services being effect of costly investments, or lowering an interest, or even resignation of programs whose results are uncertain, progress is slow or success indexes hard to measure ${ }^{8}$.

Taking a challenge of creation and development of social enterprise performance usually results from noble motives. Most often it is a consequence of strong identity of an entrepreneur with the difficulty that local communities cope with, care about increasing the level of prosperity of the poorest, will to counteract poverty and social exclusion ${ }^{9}$. Hardly ever are they driven by strictly utilitarian system of values. Hence, motivation to realize particular ambitions of the discussed units, which may appear in their pursuit to social prosperity are definitely limited, particularly in reference to small social enterprises operating locally and financed by earned profits or public means. Especially, performance on a small scale and having limited sources create conditions for lowering pressure and need of turning towards unethical policies to gain means necessary to support their actions ${ }^{10}$.

5 N. O'donohoe, Ch. Leijonhurfvnd, A. Bugg-levine, M. Brandenburgia, Impact Investments, An emerging asset class, Rockefeller Foundation, 2010, pp. 18-19.

6 A.M. Eikenberry, J.D. Kluver, The marketization of the nonprofit sector: civil society at risk?, Public Administration Review 2014/64, pp. 132-140.

7 S. Abu-Saifan, Social Entrepreneurship, Technology Innovation Management Review 2012/2, pp. 22-27.

8 L. Barendsen, H. Gardner, Is the social entrepreneur a new type of leader, Leader to Leader 2014/34, pp. 43-50.

9 S. Venkataraman, The distinctive domain of entrepreneurship research, in: J. Katz, R. Brockhaus (eds.), Advances in entrepreneurship, firm emergence, and growth, Greenwich, CT: JAI Press 1997/3, pp. 119-138.

10 S.A. Zahara, E. Gedajlovic, D.O. Neubaum, J.M. Shulman, A typology of social entrepreneurs: Motives, search process and ethical challenges, Journal of Business Venturing 2009/24, pp. 519-532. 
On a bigger scale, however, social entrepreneurs are most often oriented to the introduction of innovative solutions to cope with identified social problems, frequently of a system character ${ }^{11}$. Considerable financial needs of this kind of units require then acquisition of outer investors. Regardless of the level of capital involvement and development plans of the latter into the investments in social enterprises there is a risk of necessity to achieve specific efficiency results, taking control by an investor, growth potential or possibility of giving up the investment in confrontation of a social role and service provision in a longer time.

Withdrawal from ethical behaviors of the entities discussed does not need to result only from pressure of external investors. Motives and ambitions of social entrepreneurs themselves are complex and multidimensional, and the will to generate social prosperity is determined by hope for a great change, and even by a wish of working out a new balance for a social system in which there are serious inequalities ${ }^{12}$. Strong motivation to introduce reforms along with considerable financial means often requires egotistical actions, which go along with the desirable changes. Social entrepreneurs may make an attempt to manipulate or even pressurize others to receive their support or consent to undertaken actions. Such behaviors can be wrong, even if they lead to a greater social wealth, especially that social enterprises should be creators of positive examples and evoke trust, if they are to be effective in their performance ${ }^{13}$.

The remarks made above raise a question on a possibility of social enterprise finance in a light of ethical principles of entities that provide financial support.

\section{Ethical financing-gist and instruments}

Deliberations on ethical financing became of special importance after a long lasting financial crisis initiated by a violent crash on financial markets in 2008. A short-term credit market came to a dead stop then ${ }^{14}$. The most acute phase of the crisis, however, took place after the Lehman Brothers Bank had collapsed. As

11 J. Mair, I. Marti, Social entrepreneurship research: a source of explanation prediction and delight, Journal of World Business 2006/41 (1), pp. 36-44.

12 J.G. Dees, Enterprising nonprofits, Harvard Business Review 1998/76 (1), pp. 55-66.

13 T. Baker, R.E. Nelson, Creating Something from Nothing: Resource Construction Through Enterpreneurial Bricolage, Administrative Science Quarterly 2005/50, pp. 330-365.

14 W.W. Lang, J. Jagtiani, The mortgage and financial crisis, Financial Market Trends-OECD Journal 2009/38 (2), New York; J.S. Haley, The Global Financial Crisis, Found Press, New York 2009. 
a result, the sphere of poverty in many places all over the world enlarged, which was a significant argument in a discussion on an alternative to dominated by speculative actions modern policy of key financial entities and searching solutions promoting economic activity and social prosperity ${ }^{15}$. Despite a stimulating role of speculation visible in enhancing liquidity of financial markets its distorted character caused negative external consequences leading to separation of finances from real economy ${ }^{16}$. Negative phenomena of an excessive financialization of economy and creation of conditions leading to crisis released the need of reflection on an ethical dimension of financial markets functioning among its participants ${ }^{17}$. The debate concerns economics education reducing a high level of "financial illiteracy' ${ }^{18}$ on one hand, and on the other hand, the way in which financial markets can contribute to a proper distribution of finance products, increase stability of a financial system and awareness of ethical challenges in a globalized and highly leveraged world ${ }^{19}$. For this reason, it seems that an ethical dimension of functioning of financial markets - simplifying, should be analyzed from a perspective of a direction of development of new products, for example securitization, derivative instruments or investment strategies of financial brokers including investment funds, hedging, or private equity and the level of leveraging of finance institutions - mainly banks ${ }^{20}$.

In a narrower perspective, ethical financing has become a notion defining mainly performance of finance entities and non-finance investments in ventures for society and natural environment. In this sense, it is addressed mainly to social enterprises supporting groups of a high social exclusion risk and oriented

15 P. Mikołajczak, Krótkoterminowe kredyty bankowe dla przedsiębiorstw w warunkach kryzysu finansowego, Nauki o finansach. Financial Sciences 2014/2 (19), Wydawnictwo Uniwersytetu Ekonomicznego we Wrocławiu, Wrocław, pp. 125-126.

16 J. Bradford de Long, A. Shleifer, L.H. Summers, R.J. Waldmann, The Size and Incidence of the Losses from Noise Trading, The Journal of Finance 1989/XLIV/3, pp. 181-190.

17 I. Grabel, Financialization and Government Borrowing Capacity in Emerging Markets, by Iain Hardie, Palgrave Macmillan, London, New York 2012, pp. 1136-1139.

18 A. Raciniewska, F jak finansowy analfabetyzm, Gazeta Bankowa 2014/6 (1158), Warszawa 2014, pp. 38-43.

19 J. Kuriata, Ethics: a diet for highly leveraged financial markets, in: Trust and Ethics in Finance Innovative ideas from the Robin Cosgrove Prizes, Globethics.net Global, no. 6, Geneva 2012, pp. 55.

20 A. Janc, P. Mikołajczak, K. Waliszewski, Europejska Unia Rynków Kapitałowych. Perspektywa finansowania przedsiębiorstw w Polsce, CeDeWu, Warszawa 2015, pp. 42 and next. 
to counteracting poverty, development of economically and socially backward areas and protection of environmental resources ${ }^{21}$.

In reference to the sector of enterprises, ethical finance may concern charity performance as well as for profit, however, the aim of financial investment of a financed entity must be achievement of tangible social and/or environmental effects $^{22}$.

Among the institutions ensuring ethical finance one can distinguish - sensu stricto - ethical banks, ethical finance cooperatives/consortia and microcredit cooperatives. The first are more broadly discussed in a later part of the paper. Ethical finance cooperatives are organizations governed democratically, offering services of microfinance for low income people and small businesses, including social enterprises. Loans can be given without collateral to individual persons or in a group form ${ }^{23}$. In case of the second one, security of repayment is based on a feeling of responsibility based on awareness of necessity to meet requirements by the other members of the group who take responsibility for the loan repayment.

TABLE 1: Networks of ethical finance in Europe

\begin{tabular}{|c|l|}
\hline FEBEA - Belgium & $\begin{array}{l}\text { - It is a space of exchange of financial instruments and a platform } \\
\text { enabling input to development of existing ethical finance } \\
\text { initiatives and development of new projects }\end{array}$ \\
\hline \multirow{3}{*}{ I.N.A.I.S.E. - Spain } & $\begin{array}{l}\text { Promotes and influences development of organizations and } \\
\text { economic performance in the areas: } \\
\text { - environment, sustainable development, renewable energy } \\
\text { - social economy } \\
\text { - health and social care } \\
\text { - education, culture }\end{array}$ \\
\hline FETS - Spain & $\begin{array}{l}\text { Offering products and services for ethical business } \\
\text { - Supporting social actions }\end{array}$ \\
& $\begin{array}{l}\text { Increasing awareness and distributing information about proper } \\
\text { use of money }\end{array}$ \\
\hline
\end{tabular}

${ }^{21}$ P. Mikolajczak, W. Czternasty, Social enterprises versus globalisation, INTERCATHEDRA 2015/31/2, Poznań, pp. 43-52.

22 P. Mikołajczak, W. Czternasty, Wspieranie rozwoju przedsiębiorstw ekonomii społecznej $w$ Polsce przez fundusze europejskie. Uwarunkowania rynkowe rozwoju mikro, matych i średnich przedsiębiorstw, Mikrofirma, Wydział Zarządzania i Ekonomiki Usług Uniwersytetu Szczecińskiego, Szczecin 2015, pp. 424.

23 M.S. Sodhi, Ch.S. Tang, Social enterprises as supply-chain enablers for the poor, SocioEconomic Planning Science, 2011, pp. 146-153. 


\begin{tabular}{|c|c|}
\hline GABV - Netherlands & $\begin{array}{l}\text { - Promotes and obeys principles of 'sustainable banking' } \\
\text { - } \quad \text { Pooks for solutions to global problems } \\
\text { - Conditions for a bank joining the organization include: } \\
\text { - independence and concentration on retail customers } \\
\text { - total assets worth min. } 50 \text { million } \$ \\
\text { - involvement in social banking }\end{array}$ \\
\hline FINANSOL - France & $\begin{array}{l}\text { Promotion of solidarity financial instruments } \\
\text { Requirements of using the labels include: } \\
\text { - considering decent payment for the work done } \\
\text { - considering social and environmental aspects } \\
\text { - international solidarity } \\
\text { Certified products include: } \\
\text { - life insurance contracts } \\
\text { - investment funds (FCP, SICAV, venture capital funds etc.) } \\
\text { - saving funds for employees } \\
\text { - social enterprise shares out of stock exchange dealing } \\
\text { - current dedicated accounts and deposits } \\
\text { - solidarity bonds and microloans }\end{array}$ \\
\hline
\end{tabular}

S o u r c e: authoring on the basis of: PRICE, Wprowadzenie do etycznego finansowania odpowiedzialnych inwestycji. Przewodnik tematyczny 1, Polskie Stowarzyszenie Sprawiedliwego Handlu, Gdynia 2014, pp. 21-22.

In a broader perspective, however, it is the entities financing social enterprises or non-profit organizations, including venture philanthropy, social business angels or social venture capital that may provide the discussed capital.

Philanthropists engaged cooperate with a vast array of organizations, including those that are not charity entities but do not work for a profit at the same time. They are enterprises and social entrepreneurs, commercial charity organizations or social organizations performing commercially. In Europe, representatives of VP try to use a wide range of finance and non-finance instruments that go beyond a simple system of grants. They include shares issuing, mezzanine type finance, long-term patient capital, quasi-capital investments, equity type investments or loans ${ }^{24}$.

A group of social business angels is composed of private investors placing part of their wealth into projects which aside from generated financial results gain a social and/or environmental profit. They are not philanthropists as they are motivated by economic profits. The investors look for small social

24 M.L. Moore, F.R. Westley, A. Nicholls, The Social Finance \& Social Innovation Nexus, Journal of Social Entrepreneurship 2012/3/2. 
innovative enterprises having considerable human potential, which gives them high probability of achieving particular rate of return by participation in gains of the business ${ }^{25}$.

Performance of social business angels is completed by high risk social funds, which include social venture capital that finances social enterprises which are at a more advanced level of development. Social investors concentrated around SVC are prone to invest in companies gaining significant social or environmental impact and those which can keep such influence also facing challenges resulting from sale, take over, stock exchange debut ${ }^{26}$.

Strict criteria for social economy entities to involve in investment ventures pose some risk concerning their realization of a social mission in light of the need to meet requirements of external investors. What is more, the fact that the latter are present in structures of social enterprises greatly confines their independence and puts them at risk of being forced to accept their goals that are contradictory to the priorities of the discussed entities.

\section{Sustainable banking in social enterprise finance}

Financial crisis, as it was said before, became the reason for a public debate about the shape and ways of functioning of modern financial markets. Introduction of banking regulations was concentrated on strengthening a banking system to support real economy and improve quality of performance of banking institutions in financial security and transparency of undertaken transactions. It is visible that such an effort is also rooted in banking that is based on traditional notions of capital force and liquidity, although many representatives of a banking branch object to such a direction of changes claiming that they lead to decrease in real economy crediting ${ }^{27}$.

It was the moment of financial crisis when real banking efficiency and reliability, also referred to as ethical or social was noticed in particular. Its role is to promote social inclusion, sustainable growth, economy development and social entrepreneurship as well as increase awareness of a function of money and fallibility of economy based on a short-term achievement of profit as the only goal.

\footnotetext{
Y. Schade, Social Business Angels-Vision oder Realität? Qualitative Untersuchung zum Investitionsverhalten von privaten Investoren im sozialen Bereich, 2013.

26 H. Haugh, Community-Led Social Venture Creation, Entrepreneurship, Theory \& Practice 2007/31 (2), pp. 161-182.

27 T. Hoenig, Safe banks need not mean slow economic growth, Financial Times, 2015.
} 
The above remarks are reflected in the research conducted by GABV (The Global Alliance for Banking on Values), which analyzed aggregated financial data of all ethical banks affiliated in a network and commercial banks (G-SIFIs) ${ }^{28}$. The research was carried out in 2003-2013 and was divided into three phases. The first phase concerned pre-crisis years 2003-2007. The next one referred to post-crisis time (2008-2012), while the third phase covered the entire, more than a ten-year period, i.e. 2003-2010. Such a spectrum of research let consider two totally different periods for a banking system determined by significant changes relating to regulations within capitals, banking risk and supervision. Implifying, the degree to which a bank finances real economy results from this part of the balance sheet assets which are aimed at crediting ${ }^{29}$. Comparing, for example, the index presenting the value of credits given to overall assets, its level for sustainable banking is almost twice higher than G-SIFI's and remains of key importance for their performance. In years 2008-2012 part in a balance sheet of the assets devoted to crediting of sustainable banking increased by almost $3 \%$ comparing to pre-crisis years 2003-2007. At the same time, the analyzed index went down by almost $2 \%$ for commercial banks (G-SIFIs). In the whole researched period 2003-2012 the analyzed index representing sustainable banks was $76 \%$. It is of a note, however, that in a crisis time it was the highest $(77,4 \%)$. At the same time, analyzed commercial banks rated the lowest index in the entire analyzed period (figure 1).

The growth of number of the credits given by sustainable banks in the analyzed period against commercial banks seems interesting. It remains at a stable level, around $13 \%$. In comparison to years 2003-2007, in which the growth of the credits given was $13,6 \%$, the period of crisis did not bring about a considerable fall $(12,5 \%)$. The situation of credits in the analyzed commercial banks looked different. Growth of the finance in the whole period was $8,4 \%$ whereas it was lowest in a crisis time $(3,8 \%)$, which means a fall in relation to the previous years (2003-2007) by as much as 9,8\% (figure 2).

28 The data refer to the average rates of commercial banks qualified as of 31.12.2012 as the most important for the global financial system (G-Sifis), include: Banque Populaire CDE, Barclays, BBVA, GNP Paribas, Credit Suisse, Deutsche Bank, CreditAgricole Group, Nordea, Royal Bank of Scotland, Santander, Societe Generale, UBS, Unicredit Group.

29 I. Pyka, J. Cichorska, J. Cichy, Portfele aktywów bankowych. Analiza teoretyczno-empiryczna, CeDeWu, Warszawa 2012. 
FIGURE 1: Index of the value of the credits given to assets overall-sustainable banks vs G-SIFIs in years 2003-1012 and phases 2003-2007; 2008-2012

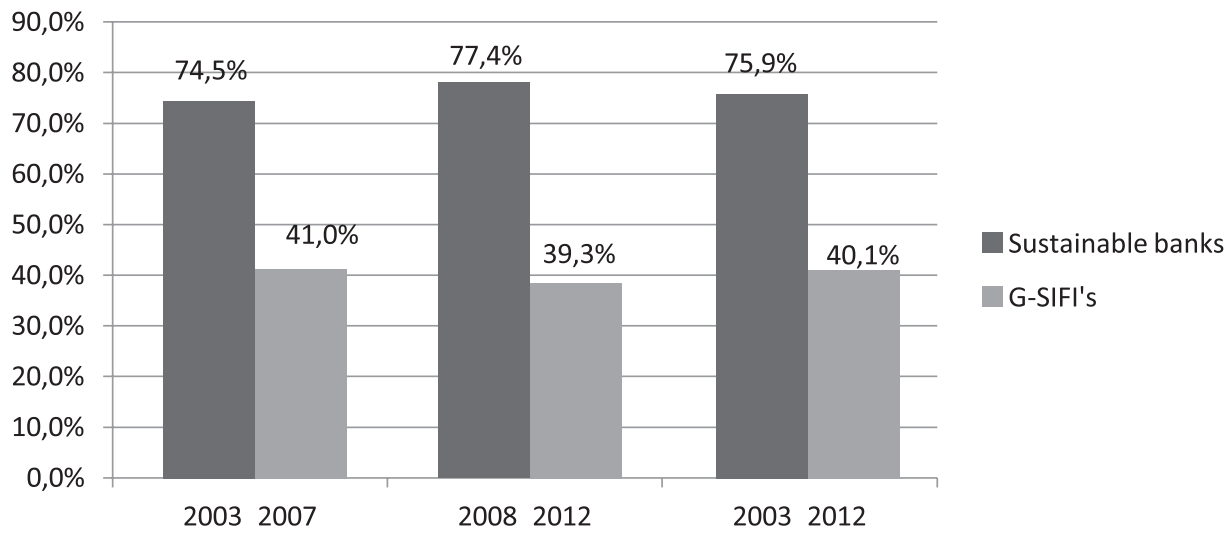

S o u r c e: authoring on the basis of data Global Alliance for banking on Values, Real Banking for the real economy: Comparing Sustainable Bank Performance with the Largest Banks in the World, 2013.

FIGURE 2: Growth of numbers of given credits - sustainable banks and G-SIFIs in years 2003-1012 and phases 2003-2007; 2008-2012

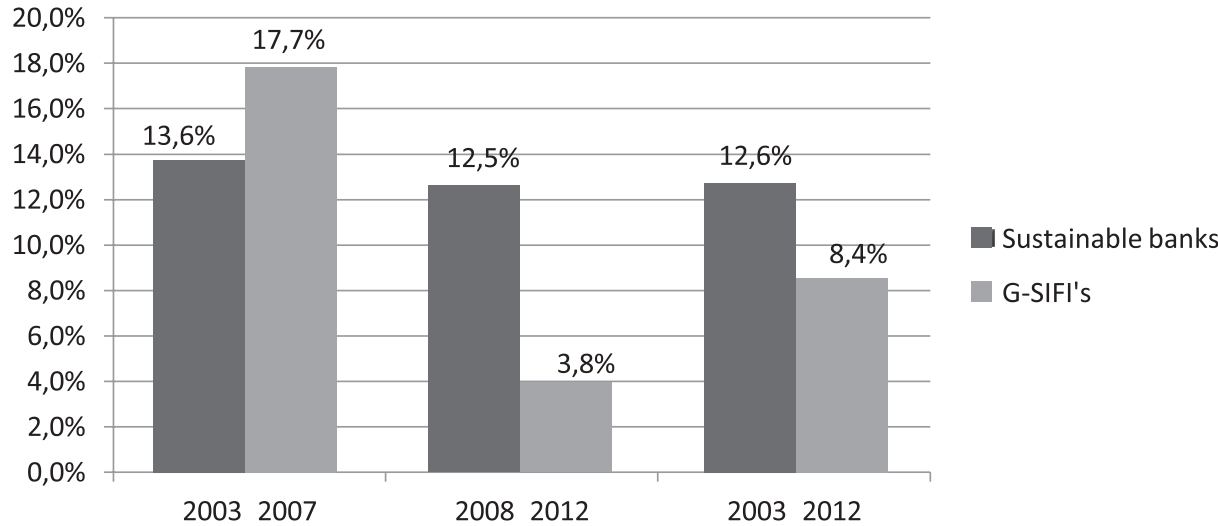

S o u r c e: authoring on the basis of data Global Alliance for banking on Values, Real Banking for the real economy: Comparing Sustainable Bank Performance with the Largest Banks in the World, 2013.

In reference to credit power, sustainable banks in comparison to G-SIFIs, more frequently rely on capital finance from their customers' deposits. Concentration on the deposit market is not only another example of tight relations of sustainable 
banking with real economy, differentiating them from a traditional sector ${ }^{30}$, but also a sign of limiting liquidity risk in a finance strategy of the discussed banks ${ }^{31}$. It is also worth paying attention to the amount and stability of deposit relation in assets overall in the analyzed phases, fluctuating around $75 \%$ (figure 3 ).

FIGURE 3: Index of the deposit values to assets overall - sustainable banks vs G-SIFIs in years 2003-1012 and phases 2003-2007; 2008-2012

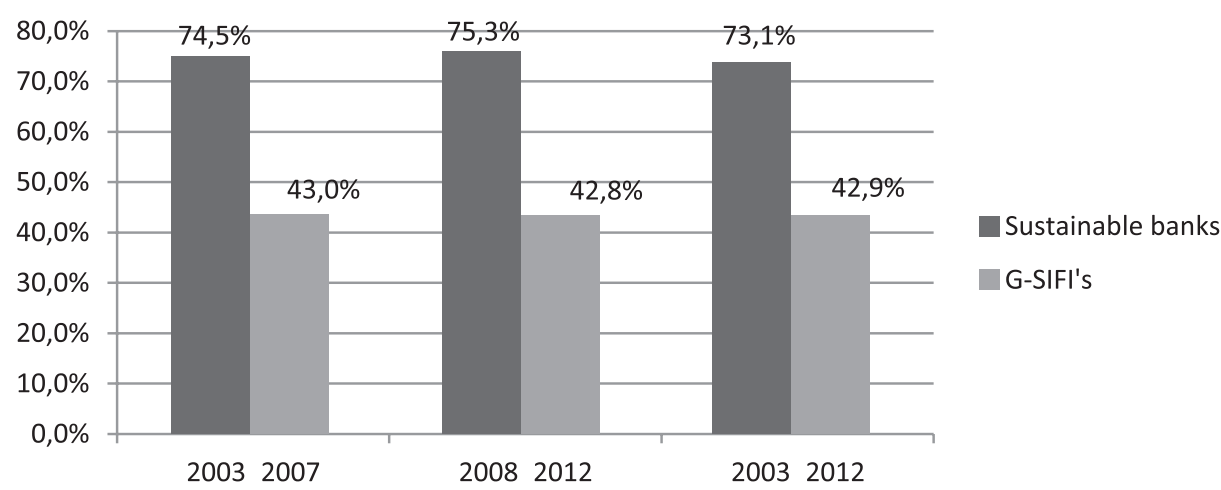

S o u r c e: authoring on the basis of data Global Alliance for banking on Values, Real Banking for the real economy: Comparing Sustainable Bank Performance with the Largest Banks in the World, 2013.

Financial results of sustainable banks indicate, they have potential to meet capital needs of social enterprises. In light of the paper aim, the question arises about credit criteria included in the mission of ethical banking sector and their adequacy to priorities of social economy entities.

It turns out that finance they receive, just like in case of commercial banks is preceded by verification of ideas for business or performance of an existing enterprise from a perspective of its chance to achieve a market success in an economic sense. Further on, they analyze non-financial perspectives of benefits in the area of local community development, ecology, diminishing poverty areas, exclusion or gaps among regions ${ }^{32}$. A sustainable bank pays special attention to initiatives supporting self-employment and/or business among women and

30 Z. Jakab, M. Kumhof, Banks are not Intermediaries of Loanable Funds-And Why This Matters, Bank of England, Working Paper 2015/529, England, pp. 11-12.

31 M. Farag, D. Harland, D. Nixon, Bank capital and liquidity, Bank of England Quarterly Bulletin 2013/53/3, England, pp. 201-215.

32 F. de Clerck, Ethical Banking, in: V. Vandemeulebroucke, K. Beck, K. Kauefer (eds.), Networking Social Finance, INAISE, Brussels 2010, pp. 16-32. 
young, often by giving microcredits and microfinance. For a sustainable bank, social and environmental effect of financed investments is as important as an economic efficiency of a venture. In a sustainable bank, project assessment is followed by the evaluation of social and environmental effects on the basis of detailed criteria, which are subject to monitoring, also after finance is given. Like in commercial banking category of profit in a policy of the discussed financial institutions is of a primary importance. Profits of a sustainable bank are mostly reinvested into social goals. From that point of view, the entities are featured as a social enterprise ${ }^{33}$.

Customers of ethical banks can count on different treatment, mostly in reference to individual and flexible venture risk assessment. The latter is limited by, among others, detailed interviews with entrepreneurs, location potential analysis, cooperation with local authorities and companies, as well as actions of numerous volunteers concentrated around social banks, who check an opinion of a financed enterprise among local community in an area of its performance, its development potential and competition. What is more, social banks are deeply rooted in reality of the territories where they perform, knowing perfectly their social and economic conditions. Thank to which they have a full knowledge about their customers and projects realized by them ${ }^{34}$.

\section{Discussion}

The above remarks let conclude that even in confrontation with repercussions on financial markets caused by crisis-regardless of their kind, social enterprises can count on stable financing of their performance by ethical banks without risking loss of independence, or giving up their social role. It must be highlighted that sustainable banking performs in accordance with strict rules achieving measurable effects. Their performance is based on a transparent combination of ethical values, well known, accepted and respected at all levels of hierarchy. Pursuit to gain financial profits is strictly related to social and environmental benefits of the financed ventures.

In the analyzed time, ethical banks successively increased their performance and preserved stability of the assets. The discussed sector of social banking

33 D. Melé, 10 Ways "Banking Sector Ethics" Can Stop Being An Oxymoron, Forbes, 22 December 2014.

34 R. Milano, Social banking: a brief history, in: O. Weber, S. Remer (eds.), Social Banks and the Future of Sustainable Finance 2011/64, New York, pp. 15-47. 
provided almost twice more credits in relation to the assets stipulated in financial balance sheets than commercial banks. It is worth noticing that the first base their performance mostly on savings collected by customers and sustain higher from average level of capitalization. They also offer bigger return of investment and lower level of alternation than commercial banks. There are some doubts, however, about the scale and scope of performance of ethical banks. The question arises whether potential of these institutions will be sufficient to increase dynamics of development of social economy entities in a different dimension - also global.

Apart from ethical banking, as the article explains there are also other entities that are defined as institutions providing social finance, which may play a complementary role towards sustainable banking. Watching their performance, however, one should pay attention to the question of dilemmas resulting from the use of support of external social investors by social enterprises. Regardless of the level of entrepreneurship and development plans, it seems reasonable that one may have fears related to the necessity of achieving particular efficiency results, investor control, growth potential, or a chance to give up the investment. Referring to the latter, it is not easy for the discussed entities to confront them with social goals and ensuring their realization in a longer perspective, and also efficiency measurement of the discussed enterprises. Some investors may visibly stress necessity to gain profits from the capital invested, even at the expense of a social mission. For that reason, social enterprises should be careful while choosing an investment partner, and clearly determine their social role that defines their performance.

\section{References}

Abu-Saifan Sam, Social Entrepreneurship, Technology Innovation Management Review 2012/2.

Baker Ted, Nelson Reed E., Creating Something from Nothing: Resource Construction Through Enterpreneurial Bricolage, Administrative Science Quarterly 2005/50.

Barendsen Lynn, Gardner Howard, Is the social entrepreneur a new type of leader, Leader to Leader 2004/34.

Bradford DeLong J., Shleifer Andrei, Summers Lawrence H., Waldmann Robert J., The Size and Incidence of the Losses from Noise Trading, The Journal of Finance 1989/XLIV/3.

Brown Adrian, Norman Will, Lighting the Touch-Paper: Growing the Social Investment Market in England, Boston Consulting Group \& the Young Foundation, Report commissioned by Big Society Capital, November 2011.

Clerck Frans De, Ethical Banking, in: V. Vandemeulebroucke, K. Beck, K. Kauefer (eds.), Networking Social Finance, Brussels, INAISE, 2010.

Dees J. Gregory, Enterprising nonprofits, Harvard Business Review 1998/76 (1). 
Eikenberry Angela M., Kluver Jodie D., The marketization of the nonprofit sector: civil society at risk?, Public Administration Review 2004/64.

Farag Marc, Harland Damian, Nixon Dan, Bank capital and liquidity, Bank of England Quarterly Bulletin 2013/53/3.

Grabel Ilene, Financialization and Government Borrowing Capacity in Emerging Markets, by Iain Hardie, Palgrave Macmillan, London, New York 2012.

Haugh Helen, Community-Led Social Venture Creation, Entrepreneurship, Theory \& Practice 2007/31 (2).

Hoenig Thomas, Safe banks need not mean slow economic growth, Financial Times, 2013.

Jajuga Krzysztof, $W$ poszukiwaniu miar ryzyka finansowego, in: Jan Czekaj, Stanisław Owsiak (eds.), Finanse w rozwoju gospodarczym i społecznym, PWE, Warszawa 2014.

Jakab Zoltan, Kumhof Michael, Banks are not Intermediaries of Loanable Funds - And Why This Matters, Bank of England, Working Paper 2015/529.

Janc Alfred, Mikolajczak Pawel, Waliszewski Krzysztof, Europejska Unia Rynków Kapitatowych. Perspektywa finansowania przedsiębiorstw w Polsce, CeDeWu, Warszawa 2015.

Kuriata Jakub, Ethics: a diet for highly leveraged financial markets, in: Trust and Ethics in Finance Innovative ideas from the Robin Cosgrove Prizes, Globethics.net Global, no. 6, Geneva 2012.

Lang William W., Jagtiani Julapa, The mortgage and financial crisis, Financial Market Trends-OECD Journal 2010/38 (2).

Mair Johanna, Marti Ignasi, Social entrepreneurship research: a source of explanation prediction and delight, Journal of World Business 2006/41(1).

Melé Domènec, 10 Ways "Banking Sector Ethics" Can Stop Being An Oxymoron, Forbes, 22 December 2014.

Mikołajczak Pawel, Krótkoterminowe kredyty bankowe dla przedsiębiorstw w warunkach kryzysu finansowego, Nauki o finansach. Financial Sciences 2014/2 (19), Wydawnictwo Uniwersytetu Ekonomicznego we Wrocławiu, Wrocław.

Mikołajczak Pawel, Czternasty Waldemar, Social enterprises versus globalisation, INTERCATHEDRA 2015/31/2, Poznań.

Mikołajczak Pawel, Czternasty Waldemar, Wspieranie rozwoju przedsiębiorstw ekonomii społecznej w Polsce przez fundusze europejskie. Uwarunkowania rynkowe rozwoju mikro, małych i średnich przedsiębiorstw, Mikrofirma, Wydział Zarządzania i Ekonomiki Usług Uniwersytetu Szczecińskiego, Szczecin 2015.

Milano Riccardo, Social banking: a brief history, in: Olaf Weber, Sven Remer (eds.), Social Banks and the Future of Sustainable Finance 2011/64, New York.

Moore Michele-Lee, Westley Frances R., Nicholls Alex, The Social Finance \& Social Innovation Nexus, Journal of Social Entrepreneurship 2012/3/2.

O'donohoe Nick, Leijonhurfvnd Christiana, Bugg-levine Antony, Brandenburgia Margot, Impact Investments, An emerging asset class, Rockefeller Foundation, 2010.

PRICE, Wprowadzenie do etycznego finansowania odpowiedzialnych inwestycji, Przewodnik tematyczny 1, Polskie Stowarzyszenie Sprawiedliwego Handlu, Gdynia 2014.

Pyka Irena, Cichorska Joanna, Cichy Janusz, Portfele aktywów bankowych. Analiza teoretyczno-empiryczna, CeDeWu, Warszawa 2012.

Raciniewska Anna, F jak finansowy analfabetyzm, Gazeta Bankowa 2014/6 (1158), Warszawa 2014. 
Ratajczak Marek, Ekonomia i edukacja ekonomiczna $w$ dobie finansyzacji gospodarki, Ekonomista 2014/2.

Sodhi ManMohan S., Tang Christopher S., Social enterprises as supply-chain enablers for the poor, Socio-Economic Planning Science, 2011.

Scott Haley J., The Global Financial Crisis, Found Press, New York 2009.

Schade Yvonne, Social Business Angels - Vision oder Realität? Qualitative Untersuchung zum Investitionsverhalten von privaten Investoren im sozialen Bereich, 2013.

Venkataraman Sankaran, The distinctive domain of entrepreneurship research, in: J. Katz, R. Brockhaus (eds.), Advances in entrepreneurship, firm emergence, and growth, Greenwich, CT: JAI Press 1997/3.

Weber Olaf, Sustainable Banking-History and Current Developments, Social Science Research Network 2016/1.

Zahara Shaker A., Gedajlovic Eric, Neubaum Donald O., Shulman Joel M., A typology of social entrepreneurs: Motives, search process and ethical challenges, Journal of Business Venturing 2009/24.

Paweł MIKOŁAJCZAK

\section{BANKOWOŚĆ ZRÓWNOWAŻONA. IMPLIKACJE DLA ETYCZNEGO WYMIARU FINANSOWANIA DZIAŁALNOŚCI PRZEDSIĘBIORSTW SPOŁECZNYCH}

\section{(Streszczenie)}

W artykule dokonano oceny potencjału bankowości zrównoważonej jako istotnego elementu systemu finansowania etycznego, zasilającego kapitałowo przedsiębiorstwa społeczne. Wskazano alternatywny charakter bankowości etycznej wobec zagrożeń wynikających z zaangażowania społecznych inwestorów zewnętrznych w przedsięwzięcia inwestycyjne realizowane przez przedsiębiorstwa społeczne. W tym celu przeprowadzono analizę wybranych wskaźników finansowych banków etycznych na tle komercyjnych instytucji bankowych oraz dokonano oceny zasad i kryteriów udzielania finansowania przez bankowość zrównoważoną. Wnioskowanie odniesiono do pozakredytowych form zasilania kapitałowego przedsiębiorstw społecznych.

Słowa kluczowe: bankowość zrównoważona; społeczna przedsiębiorczość; kredyt; finansowanie etyczne 